Journal of Environmental Science and Public Health

doi: $10.26502 /$ jesph. 96120047

Volume 3, Issue 1

Review Article

\title{
Chemical Contaminants and Pollutants in the Measurable Life of Dhaka City
}

\author{
Mohiuddin AK* \\ Department of Pharmacy, World University of Bangladesh, Dhaka, Bangladesh \\ "Corresponding Author: Mohiuddin AK, Department of Pharmacy, World University of Bangladesh, 151/8, \\ Green Road Dhanmondi, Dhaka-1205, Bangladesh, E-mail: trymohi@gmail.com
}

Received: 29 November 2018; Accepted: 10 December 2018; Published: 24 January 2019

\begin{abstract}
Environmental pollution and food contamination are as old as the civilization itself. It is the consequence of the development of civilization, over utilization of nature, industrialization and in fact a price for the progress. It is highly prominent in Dhaka city. Air pollution is mainly due to the vehicle emission, industrial discharge and burning of fossil fuel. The water resource of Dhaka becomes a major health threat due to arsenic contamination, inadequate household/industrial/medical waste disposal and industrial effluent management. Food contamination came from the commercialism of business people who are doing this knowingly to maximize profit. Necessary steps are to be taken to protect the environment for our own existence. This paper reveals chemical pollution and contamination issues of Dhaka city, the capital of Bangladesh.
\end{abstract}

Purpose of the study: Brief review of chemical induced pollution and contamination, their consequences and control. Healthcare providers/Policy makers have a major role play to concerned field.

Materials and Methods: Comprehensive literature search followed by consulting healthcare professionals about environmental pollution and food contamination. Hospital, clinic and company personnel, newspaper journalists, NGO workers given their valuable suggestions and asked help for necessary books, journal, newsletters. A few western magazine and newspapers also observed to get necessary concern. Projections were based on public life pattern, their food habits, pollution and contamination sources, waste disposal features of urban life as well as industry and hospital waste disposals. 
Results and Discussions: Pollution and adulteration are the most notorious enemy of mankind. Civilization has its own drawback that even causing destruction of itself. Very few people raised voice on this but crippled by the facts of commercialism. The scope of this article is limited to chemical pollution of air and water, medical or household waste products and food contaminants and adulterants. A few discussions based on real life experience and recent studies or reports from various journals and news articles are summarized here.

Findings: Both general people and the old system, are responsible for this unlivable condition of Dhaka city. Population is not the sole for this instance. A sense of poor rules and regulation is always raised everywhere. Negligence is becoming a contagious disease contaminating illiterate to well educated, all kind of people.

Research limitations: Many articles and documents found in concerned area of research, but the scope of this research is on its focus point chemical hazards and burdens of Dhaka city. Still the most important aspect is covered, but fact is less amount of recent data found in few areas.

Practical Implication: The language of this article is too simple to understand by people with simple literacy. Journalists, doctors, students, nurses, pharmacists, public representatives, policy makers and regulatory authorities have to acquire much from this article.

Social Implication: Any article or research is based on the think beneficence for mankind, at least going ahead from the present situation, overwhelming problems and measures. The article should create a direction for the future policy makers of both government and other sectors to review the frustrating situation of chemical pollutions and food contaminants of Dhaka, along with the whole Bangladesh. Again, world business is moving to Asian countries, Bangladesh will be a major business hub within next few decades. This article should remind policy makers that we should not forget mankind, giving places to industrialization and development.

Keywords: Medical and Household waste; Health Hazard; Chemical Intoxication; Cancer; Food Poisoning; Pathogen; Contaminants; Civilization

Abbreviations: BDL-Below Detection Limit; BOD-Biochemical Oxygen Demand, also called Biological Oxygen Demand; COD-Chemical Oxygen Demand; DO-Dissolved Oxygen; TDS-Total Dissolved Solid; PH-A logarithmic scale used to specify the acidity or basicity of an aqueous solution; ICDDR, B-International Centre for Diarrheal Disease Research, Bangladesh

\section{Introduction}

Contamination is the presence of an unwanted substance where it should not be or at concentrations above recommended. Pollution is contamination that results in detrimental biological effects to resident communities. All pollutants are contaminants, but not all contaminants are pollutants. All elements of the natural environment can be 
altered, sometimes with harmful results. Air, food, water, and the earth can all become sources of ailment, in the home, public, or work environments. In urbanization, all processes are viewed in relation to the city. Generally, better utility, good medical care, better food supply, education scope, jobs, industrialization, entertainment, electrification, specialization of professions are the basic causes of huge urban population growth. Better access to utilities and energy plays an important role in city development-with this, people can relish all the modern facilities. Undeveloped areas got connected with road communication. It brings the people from those areas, for the use of media, technology, information for more standard living. With increased civilization and industrialization, both air and water, in Western or developing countries, contaminates with toxic substances that are either direct results of discharge or produced by photochemical degradation. Dhaka, being the capital of Bangladesh ranked $3^{\text {rd }}$ worst in Air Quality Index (AQI) in the world. Besides, the city of nearly 20 million inhabitants, Dhaka faces challenges on this front, ranging from chemical outpouring, poor sanitation, river and canal water pollution from the surrounding industries, all resulting from the impromptu nature of urban civilization. Food contaminants and adulterants gave a new dimension in city life, together rest of the country. The healthcare providers role in environmental health is related principally to being alert to the conditions predominant in the community and of working with others to adequately control any of the attendant hazards.

\section{Urbanization and Its Impact}

Urbanization is one of $21^{\text {st }}$ century's most developing trends. Cities are the dominant force in continual economic growth, development, and prosperity in both advanced and developing countries. In developed countries, the growth of the urban population has stabilized, and urbanization is taking place rapidly. Currently, 55\% of the world's population (four billion people) reside in urban areas which will be nearly $70 \%$ by 2050 [1]. By 2030, over $60 \%$ people will live in the cities (Megacity Challenges, Siemens AG), two billion more people will have migrated to cities-placing uncommon pressure on infrastructure and resources, particularly those related to water (According to UN and World Bank) [2]. From 2016 to 2030, a 35\% population growth is expected in the top ten megacities. Furthermore, as more than three-quarters (around 80\%) of the world's mega-cities are coastal, there will be a substantial impact on water ecosystems from ridge to reef. Because of this, local and regional authorities lead actions targeting water-related obstacles, including energy and water, an increased demand for food, housing gaps and climate change $[3,4]$.

Forecasts indicate cities in developing countries including Dhaka, Karachi and Lagos will surpass cities like Osaka, New York and Sao Paulo by 2030 [5]. It demands an extra 50\% energy and water that pressurize the sources and threaten global water security. This has an apparent effect on both economic development and public health. It has been predicted that the urban population in Bangladesh will rise to between 90 and 100 million by 2050, which will be around $50 \%$ of the total population [6]. The leather tanning industry has been identified as one of the main causes of pollution in the Capital city of Dhaka of 10 million people of both environment and water. About 60,000 tons of row hides and skins are processed every year using chloride and ammonium sulphate, followed by dehairing during de-liming, solvent vapors release a huge volume of crude effluent into the open causing air and water pollution [7]. 


\section{Chemical Pollution and Contamination Due to Urbanization}

Smog results from the interaction of the ultraviolet rays in sunshine and the unburned hydrocarbons of automobile engines or factories and smokestacks. These products, when trapped by the thermal inversion engendered by local topography, cause damage to mucous membranes and lungs when inhaled [8]. Acute episodes of air pollution have been found to exacerbate illness and even cause death in people who already have respiratory and cardiovascular diseases. Supporting evidence exists demonstrating that second-hand tobacco smoke increases the risk of cardiovascular diseases or cancer as well [9]. According to World Bank's Country Environmental Analysis (CEA) 2018 report, air pollution lead to deaths of 46,000 people in yearly in Bangladesh [10]. Waterborne infectious disease is very common today, all the public supplies are literally contaminated with water drainage system reported many places. Many complaints about the taste, appearance, and physical qualities of locally supplied water have led to a brisk in bottled water [11]. Water contamination with ground-source chemicals (e.g. pesticides, fertilizers) remains an ongoing possibility. Food remains a significant vehicle of disease organisms [12]. Foodborne disease, more commonly but often incorrectly called "food poisoning," is grossly underreported. In most instances the illness produced by contaminated food is mild and of short duration, but more severe outbreaks (such as hepatitis A, most commonly seen in public restaurants) can. Epidemics of food-borne disease are dramatic and sudden, and most people become sick within 6 to 24 hours after consuming the contaminated foodstuffs. The epidemic pattern of food-borne disease presents differently from the gastrointestinal symptoms (e.g. nausea, vomiting, and diarrhea) induced by intestinal enteroviruses occur [13].

\section{The Dhaka City at a Glance}

Living in Dhaka city endowed with a traffic jam, street foods, unplanned buildings, narrow road space, noise pollution along with environmental pollution and issues of contamination [14]. Some people make joke like "Traffic jams teach us things like patience and how to plan ahead of time" [15]. Many people sleep roadsides, railway platforms, mosques and market places. People rushes this city for job, business and other opportunities like uninterrupted utilities. Along with general people, the city is also heaven for muggers, robbers, thieves, pickpockets, frauds, drug dealers and organized criminals [16]. People rarely can see the sunrise or sunset due to thousands of buildings. Hawkers are illegally occupying the public walkways, pedestrians are now forced to walk on the roads which raises the risks of accidents and adds to the already unbearable traffic congestion in those areas. Economist Intelligence Unit (EIU) surveyed 140 cities around the world for its Global Live-ability Index 2018, scoring them on over 30 specified parameters under five categories: Infrastructure, education, culture and environment and healthcare facilities [17]. All these things make this a difficult to breath place and a second worst place in the world to live in. Some 18,000 deaths from environmental pollution took place in 2015 in Dhaka [18].

\subsection{Air pollution}

The most profound chemicals found harmful to human health and at high enough concentrations (Table 1) can even be fatal are Carbon monoxide (CO), Sulfur dioxide $\left(\mathrm{SO}_{2}\right)$, Nitrogen oxides (NOx), Ozone $\left(\mathrm{O}_{3}\right)$, Hydrocarbons $(\mathrm{HC})$ 
and Suspended Particulate Matter (SPM) found in places surround Dhaka. Possible health hazards found to be headache, eye-nose-throat irritation, allergy, lung injury, trauma and even death with long term exposure [19-21].

\begin{tabular}{|c|c|c|c|c|c|c|c|c|}
\hline \multirow[b]{2}{*}{$\begin{array}{l}\text { Air } \\
\text { Pollutants }\end{array}$} & \multicolumn{8}{|c|}{ Estimated Coefficient Trend at Different Locations } \\
\hline & $\begin{array}{l}\text { Savar, } \\
\text { Brick } \\
\text { Field } \\
\text { Areas }\end{array}$ & $\begin{array}{l}\text { Dhaka } \\
\text { Cantonment }\end{array}$ & $\begin{array}{l}\text { West } \\
\text { Rasulpur, } \\
\text { Dhaka }\end{array}$ & $\begin{array}{l}\text { Birulia, } \\
\text { Savar }\end{array}$ & $\begin{array}{l}\text { North of } \\
\text { DEPZ, } \\
\text { Savar }\end{array}$ & $\begin{array}{l}\text { South of } \\
\text { DEPZ, } \\
\text { Savar }\end{array}$ & $\begin{array}{l}\text { East of } \\
\text { DEPZ, } \\
\text { Savar }\end{array}$ & $\begin{array}{l}\text { West of } \\
\text { DEPZ, } \\
\text { Savar }\end{array}$ \\
\hline $\begin{array}{l}\text { Volatile } \\
\text { Organic } \\
\text { Carbon } \\
\text { (VOC) } \\
\mathrm{mg} / \mathrm{kg}\end{array}$ & $\begin{array}{l}2.547 * * * \\
-0.0017 \\
{[0.974]}\end{array}$ & $\begin{array}{l}1.571 * * \\
-0.03166 \\
{[0.8291]}\end{array}$ & $\begin{array}{l}0.595 * * * \\
-0.0023 \\
{[0.9687]}\end{array}$ & $\begin{array}{l}1.075^{* * *} \\
-0.0042 \\
{[0.9541]}\end{array}$ & $\begin{array}{c}0.846^{* *} \\
-0.0424 \\
{[0.793]}\end{array}$ & $\begin{array}{l}1.834 * * \\
-0.0367 \\
{[0.811]}\end{array}$ & $\begin{array}{l}1.587 * * \\
-0.04 \\
{[0.801]}\end{array}$ & $\begin{array}{l}0.819 * * \\
-0.042 \\
{[0.7953]}\end{array}$ \\
\hline $\begin{array}{l}\text { Carbon } \\
\text { dioxide } \\
\left(\mathrm{CO}_{2}\right) \\
\mathrm{mg} / \mathrm{kg}\end{array}$ & $\begin{array}{l}0.070^{*} \\
-0.134 \\
{[0.580]}\end{array}$ & $\begin{array}{l}0.115^{* *} \\
-0.0466 \\
{[0.78125]}\end{array}$ & $\begin{array}{l}0.088^{* *} \\
-0.0217 \\
{[0.8659]}\end{array}$ & $\begin{array}{l}0.123 \\
-0.302 \\
{[0.339]}\end{array}$ & $\begin{array}{l}0.024 \\
-0.8596 \\
{[0.0122]}\end{array}$ & $\begin{array}{l}0.06 \\
-0.00004 \\
{[0.9976]}\end{array}$ & $\begin{array}{l}0.181 \\
-\end{array}$ & $\begin{array}{l}0.520^{* *} \\
-0.046 \\
{[0.781]}\end{array}$ \\
\hline $\begin{array}{l}\text { Carbon } \\
\text { monoxide } \\
(\mathrm{CO}) \\
\mathrm{mg} / \mathrm{kg}\end{array}$ & $\begin{array}{l}0.218^{* * *} \\
-0.0027 \\
{[0.965]}\end{array}$ & $\begin{array}{l}2.092 * * \\
-0.0355 \\
{[0.815]}\end{array}$ & $\begin{array}{l}0.349 \\
- \\
0.00000661 \\
{[0.999]}\end{array}$ & $\begin{array}{l}1.268^{* *} \\
-0.0388 \\
{[0.8053]}\end{array}$ & $\begin{array}{l}1.085^{* * *} \\
-0.0002 \\
{[0.9934]}\end{array}$ & $\begin{array}{c}0.880 * * * \\
-0.00146 \\
{[0.9772]}\end{array}$ & $\begin{array}{l}1.051^{* *} \\
-0.013 \\
{[0.9038]}\end{array}$ & $\begin{array}{l}0.708^{* * *} \\
-0.0009 \\
{[0.9827]}\end{array}$ \\
\hline $\begin{array}{l}\text { Oxygen } \\
\left(\mathrm{O}_{2}\right)(\%)\end{array}$ & $\begin{array}{l}0.825 \\
-0.32 \\
{[0.3200]}\end{array}$ & $\begin{array}{l}0.134 \\
-0.854 \\
{[0.0131]}\end{array}$ & $\begin{array}{l}3.094 * * \\
-0.0466 \\
{[0.78125]}\end{array}$ & $\begin{array}{l}0.392 * \\
-0.0605 \\
{[0.7422]}\end{array}$ & $\begin{array}{l}0.455 \\
-0.1456 \\
{[0.560]}\end{array}$ & $\begin{array}{l}1.093 * * * \\
-0.0018 \\
{[0.9730]}\end{array}$ & $\begin{array}{l}0.869 \\
- \\
0.000000005 \\
{[0.9999]}\end{array}$ & $\begin{array}{l}0.442 \\
-0.14278 \\
{[0.565]}\end{array}$ \\
\hline $\begin{array}{l}\text { Relative } \\
\text { Humidity } \\
(\%)\end{array}$ & $\begin{array}{l}0.165 \\
-0.6392 \\
{[0.0825]}\end{array}$ & $\begin{array}{l}-0.082 \\
-0.4686 \\
{[0.185]}\end{array}$ & 0 & 0 & \begin{tabular}{|l}
0.125 \\
-0.224 \\
{$[0.4375]$}
\end{tabular} & $\begin{array}{l}-0.095^{*} \\
-0.0625 \\
{[0.7369]}\end{array}$ & $\begin{array}{l}0.125^{*} \\
-0.0823 \\
{[0.6879]}\end{array}$ & $\begin{array}{l}0.197 * * * \\
-0.0004 \\
{[0.9889]}\end{array}$ \\
\hline $\begin{array}{l}\text { Sulfur } \\
\text { Dioxide } \\
\left(\mathrm{SO}_{2}\right) \\
\mathrm{mg} / \mathrm{kg}\end{array}$ & $\begin{array}{l}0.880 * * \\
-0.0119 \\
{[0.9089]}\end{array}$ & $\begin{array}{l}4.616^{*} \\
-0.0546 \\
{[0.7582]}\end{array}$ & $\begin{array}{l}1.352 * * * \\
-0.0008 \\
{[0.9836]}\end{array}$ & $\begin{array}{l}4.671^{* *} \\
-0.0502 \\
{[0.7708]}\end{array}$ & $\begin{array}{l}0 \\
-\end{array}$ & $\begin{array}{l}0 \\
-\end{array}$ & $\begin{array}{l}8.377^{* *} \\
-0.0137 \\
{[0.9005]}\end{array}$ & $\begin{array}{l}1.494 * \\
-0.0615 \\
{[0.739]}\end{array}$ \\
\hline $\begin{array}{l}\text { Nitrogen } \\
\text { Oxide } \\
(\mathrm{NOx}) \\
\mathrm{mg} / \mathrm{kg}\end{array}$ & $\begin{array}{l}3.233^{* *} \\
-0.0144 \\
{[0.8972]}\end{array}$ & $\begin{array}{l}4.768^{* *} \\
-0.0456 \\
{[0.7843]}\end{array}$ & $\begin{array}{l}2.770 * * \\
-0.0508\end{array}$ & $\begin{array}{l}1.918^{* *} \\
-0.0466 \\
{[0.78125]}\end{array}$ & $\begin{array}{l}2.920 * * \\
-0.0466 \\
{[0.78125]}\end{array}$ & $\begin{array}{l}1.698 * * \\
-0.0466 \\
{[0.78125]}\end{array}$ & $\begin{array}{l}1.671 * * \\
-0.0466 \\
{[0.78125]}\end{array}$ & $\begin{array}{l}2.561 * * \\
-0.0466 \\
{[0.78125]}\end{array}$ \\
\hline
\end{tabular}




\begin{tabular}{|l|l|l|l|l|l|l|l|l|}
\hline Hydrogen & $0.435^{* * *}$ & -2.35 & $1.521^{* *}$ & 0.547 & $1.823^{* *}$ & 1.806 & 1.339 & $0.652^{*}$ \\
$\begin{array}{l}\text { Sulfide } \\
\left(\mathrm{H}_{2} \mathrm{~S}\right)\end{array}$ & -0.0003 & -0.5512 & -0.0273 & -0.7802 & -0.0427 & -0.123 & -0.153 & -0.0606 \\
$\mathrm{mg} / \mathrm{kg}$ & {$[0.9917]$} & {$[0.1298]$} & {$[0.8445]$} & {$[0.0301]$} & {$[0.7930]$} & {$[0.600]$} & {$[0.5458]$} & {$[0.7420]$} \\
\hline
\end{tabular}

Table 1: Coefficient trend of air pollutant parameters at different locations in the city of Dhaka (July 2016- June, $2017[21]$.

The AQI in Dhaka during the winter, where more than 4,500 brick kilns operate, typically wavers above 250 -a level expressed unhealthy for all groups-but often spikes much higher [22]. Brick kilns, unfit vehicles run by fuels with higher level sulphur, as well as construction works, rundown roads have been identified as major sources of air pollution $[23,24]$. Day by day the amount of dust include air pollution in the city has been increasing. The air quality, particularly in Dhaka has assuredly been getting worse. Air pollution, according to Thomson Reuters Foundation, caused largely by burning fossil fuels, is cutting global life assumption by an average of 1.8 years per person, making it the world's top killer [25]. AQI 201 to 300 is marked as "extremely unhealthy" or hazardous air. At present AQI level of Dhaka has 309, which is in extreme "unhealthy" position [10].

\subsection{Water pollution}

Moving on to the issue of water quality and pollution, the National Sustainable Development Strategy (NSDS) of Bangladesh identifies the following reasons behind degradation of surface water quality:

1. Insufficient enforcement of environmental regulations

2. Confusion about institutional responsibility for the quality of urban water bodies

3. Encroachment of rivers and water bodies

4. Rural-to-city migration

5. Unregulated industrial expansion [26].

The Rivers Buriganga, Shtalakhka, Balu, Tongi Khal and dholeswari which runs past Dhaka City, is at present one of the most contaminated rivers in Bangladesh [27]. The city is suffering from an acute lack of domestic water supply. Water is involved in the spread of contagious diseases in essentially two ways. The well-known direct ingestion of infectious agent when drinking contaminated water. The second is due to a lack of sufficient water for personal solitariness purposes [28]. Approximately $80 \%$ of all sicknesses and diseases can be attributed to inadequate water supply and sanitation worldwide [29, 30]. However, the rivers and canals continued to be intervened, and more wastewater from houses and industrial units poured into the rivers without any treatment, with several major sources of contaminats being outside the city area-in Gazipur, Tongi, Savar, Ashulia [31]. According to Dhaka Water Supply and Sewerage Authority (DWASA), it can currently supply $75 \%$ of water demand, out of which $85 \%$ is from groundwater sources (Deep Tube wells) [32]. The presence of toxic metal lead in Elephant road, 
Dhaka.University, Jatrabari, and Demra area and toxic Pentachlorophenol (PCP) and actual pathogenic bacterial load in the WASA supplied drinking water from different areas of Dhaka city were found to be ineligible for human utilization (Table 2).

\begin{tabular}{|l|l|l|l|l|l|l|}
\hline Sample No. & Sampling Area & $\begin{array}{l}\text { Pb content } \\
(\mathbf{m g} / \mathbf{L})\end{array}$ & $\begin{array}{l}\text { Td content } \\
(\mathbf{m g} / \mathbf{L})\end{array}$ & $\begin{array}{l}\text { Cr content } \\
(\mathbf{m g} / \mathbf{L})\end{array}$ & $\begin{array}{l}\text { As content } \\
(\boldsymbol{\mu g} / \mathbf{L})\end{array}$ & $\begin{array}{l}\text { Total Bacterial Count } \\
\text { c.f.u./100 } \mathrm{mL}\end{array}$ \\
\hline 1 & Dhaka University & 0.52 & 0.05 & BDL & 0.78 & $4.0 \times 105$ \\
\hline 2 & Bangshal & BDL & 0.03 & BDL & 0.43 & $2.1 \times 104$ \\
\hline 3 & DMCH & BDL & 0.04 & BDL & 0.25 & $1.0 \times 104$ \\
\hline 4 & Basabo & BDL & BDL & BDL & 5.12 & $4.2 \times 106$ \\
\hline 5 & Komlapur & BDL & BDL & BDL & 0.21 & - \\
\hline 6 & Badda & BDL & 0.04 & BDL & 1.29 & $1.0 \times 105$ \\
\hline 7 & Sobujbagh & BDL & 0.04 & BDL & 0.42 & $5.2 \times 106$ \\
\hline 8 & Shagun Bagichaa & BDL & 0.06 & BDL & BDL & $5.0 \times 103$ \\
\hline 9 & Demra & 0.46 & 0.07 & BDL & 0.44 & - \\
\hline 10 & Jatrabari & 0.51 & 0.07 & BDL & 0.15 & $1.5 \times 104$ \\
\hline 11 & Mohammadpur & BDL & 0.07 & BDL & 0.53 & $5.0 \times 103$ \\
\hline 12 & Panthapath & BDL & 0.07 & BDL & 0.29 & $3.0 \times 104$ \\
\hline 13 & Elephant Road & 0.53 & 0.08 & BDL & 0.10 & $2.5 \times 104$ \\
\hline 14 & Shampur & BDL & 0.08 & BDL & 0.56 & $3.5 \times 104$ \\
\hline
\end{tabular}

*table 2 contents accommodated in 1

Table 2: Lead, Cadmium, Chromium and Arsenic content in first 14 water samples [33]*.

Some $80 \%$ of wastes are being discharged into the rivers in Bangladesh. No wonder our water supplies are in unsecured. Around 250 industries are liberating chemical contaminants into the Buriganga and Sitalakhya river. Every day 4000 tons of solid and 22, 000 tons of tannery waste assimilates with water in Buriganga river. Sewage is being discharged directly into the rivers, and the low-lying parts around urban areas [34]. By 2021 the garments export target has been set at $\$ 50$ billion. But the success comes at a huge substantial cost. The dyeing and finishing plants are the major contaminants of water. Turag that flows by Tongi is almost dead with pollution. Its water looks ink black and gives out such a bizarre smell [35]. Wetlands around Dhaka city are being demolished through land development and scrapping of toxic effluents and crude sewage. Industrial effluents have totally destroyed the ecology of rivers near these large urban areas [6]. In Dhaka, 20 canals have escaped. Liquid and solid wastes, and heavy metals like copper, iron, lead, and nickel are deploring the BOD, COD, DO, TDS, PH of water [7].

\subsection{Medical and household solid waste}

Dhaka City Corporation (DCC) is unable to impose rules on the public. On the institutional side, rules and governance are not clear. The role and liabilities of waste generators are not clearly defined i.e., the present law does 
not provide forfeits for illegal discharge of waste or dumping. Lack of scientific measures for problem solving and DCC has shortages of proficient human resources and finances [36]. The accrued waste is junked by the inhabitants in the city's streets, open storm water and wastewater drains or open water bodies where and whenever the collection service is non-existent or not functioning properly [37]. In particular, slum or peripheries are afflicted by such a bearing. During the annual monsoon rains and storm water effluents which are clogged by solid waste overflow, creating an acute sanitary and wholesome threat in low-lying slum areas particularly. Solid waste generation profile is Per Capita Waste Generation: $0.56 \mathrm{~kg} / \mathrm{cap} /$ day, Total Waste Generation DCC Area: 5000 tons/day and $70 \%-80 \%$ of the solid waste is organic. Around 200 metric tons of medical wastes are engendered in the city per day (Approximately 6\% of total waste) [38]. Different industries and their discharges to pollution in Dhaka are: fertilizers/pesticides (6.6\%), food industry (12.1\%), pharmaceuticals (15.9\%), metals (14\%), Pulp and paper $(47.4 \%)[34,39,40]$.

\begin{tabular}{|l|l|}
\hline Waste Category & Description with Examples \\
\hline Infectious waste & $\begin{array}{l}\text { Pathogens may be present. e.g. excreta, laboratory cultures, tissues, materials or } \\
\text { equipment that have been in contact with infected patient. }\end{array}$ \\
\hline Pathological waste & Human tissues or fluids. e.g. blood and other body fluids, fetuses. \\
\hline Pharmaceutical waste & $\begin{array}{l}\text { Wastes containing pharmaceuticals. e.g. pharmaceuticals that are no longer needed or } \\
\text { expired }\end{array}$ \\
\hline Genotoxic waste & $\begin{array}{l}\text { Waste containing substances with genotoxic properties. e.g. waste containing } \\
\text { cytotoxic drugs (often used in cancer therapy); genotoxic chemicals. }\end{array}$ \\
\hline Chemical waste & $\begin{array}{l}\text { Chemical substances present in a waste. e.g. laboratory reagents, film developer; } \\
\text { disinfectants that are expired or no longer needed; solvent. }\end{array}$ \\
\hline Wastes with high content of & Batteries, broken thermometers, blood-pressure gauges. \\
\hline Preavy metals & Gas cylinders, aerosol cans \\
\hline Radioactive waste & $\begin{array}{l}\text { Radioactive substances present in a waste. e.g. unused liquids from radiotherapy or } \\
\text { laboratory research, contaminate glassware, packages or absorbent paper. }\end{array}$ \\
\hline Sharps & Sharp wastes. E.g. needles, knives, blades, broken glass infusion sets. \\
\hline
\end{tabular}

Table 3: Medical Waste of different categories.

Medical waste may contain highly toxic chemicals and can present a mechanism for conveyance of diseases (Table 3). The growth of the medical sector around the world over the last decade connected with an increase in the use of disposable cheap medical products has contributed to the large amount of medical waste being generated. For a megacity like Dhaka, even less harmful wastes generation rates can lead to the gathering of large quantity wastes [41]. This large amount of medical waste poses from different healthcare establishment (HCE) (Table 4) significant health risks to the people correlated with waste disposal and treatment. During monsoon, the situation gets worse as medical, toxic chemicals and sewage waste flood Dhaka streets, polluting dozens of surrounding areas in the 
process. The reuse of syringes by the general public represents one of the greatest public health problems in the developing world related to health care waste. Worldwide, an estimated 10 to 20 million infections of Hepatitis B and $\mathrm{C}$ and HIV occur annually from the reuse of discarded syringe needles without prior sterilization [42].

\begin{tabular}{|c|c|c|c|c|c|c|c|}
\hline \multirow[t]{2}{*}{ Color } & \multirow[t]{2}{*}{ Type of wastes } & \multicolumn{6}{|c|}{ Amount (in kg) } \\
\hline & & DMCH & ВМСH & GH** & $\mathrm{PC}^{* *}$ & DC** & Total \\
\hline Black & $\begin{array}{l}\text { General waste Kitchen } \\
\text { waste, medicine box) }\end{array}$ & $2587(79.01)$ & 563 (83.65) & $729(77.31)$ & $286(75.26)$ & 143 (48.97) & $4308(77.45)$ \\
\hline Yellow & $\begin{array}{l}\text { Infectious waste } \\
\text { (Cotton bandage, } \\
\text { amputated body parts, } \\
\text { placenta, blood and } \\
\text { urine bags) }\end{array}$ & 489 (14.94) & $59(10.57)$ & $132(14.00)$ & $46(12.10)$ & 57 (19.52) & 783 (14.08) \\
\hline Green & $\begin{array}{l}\text { Plastic waste (Syringe } \\
\text { without needle, saline } \\
\text { bags, gloves) }\end{array}$ & $79(2.41)$ & $18(3.22)$ & $32(3.39)$ & $21(5.53)$ & 63 (21.57) & $213(3.83)$ \\
\hline Red & $\begin{array}{l}\text { Sharp items (needle, } \\
\text { blade, knife, Vial- } \\
\text { ampoule) }\end{array}$ & $36(1.10)$ & $6(1.07)$ & $12(1.27)$ & $9(2.37)$ & $6(2.06)$ & $69(1.24)$ \\
\hline Blue & Liquid waste & $83(2.53)$ & $27(4.83)$ & $38(4.03)$ & $18(4.74)$ & $23(7.88)$ & $189(3.40)$ \\
\hline Total & & $3274(100 \%)$ & $673(100 \%)$ & $943(100 \%)$ & $380(100 \%)$ & $292(100 \%)$ & $5562(100 \%)$ \\
\hline
\end{tabular}

DMCH-Dhaka Medical College Hospital; BMCH-Bangladesh Medical College Hospital; GH-General Hospitals; PC-Private Clinics; and DC-Diagnostic Centers

Table 4: Amount of wastes with types generated in different HCEs in Dhaka city.

\subsection{Food contamination}

Dhaka city now alone generates huge solid wastes per day from industrial discharge, fertilizers, fossil fuels, sewage sludge and municipality wastes and they are the major sources of heavy metals in soils and subsequent uptake by crops, vegetables and other food items causing serious health hazards to human beings [43-45]. A significant discharge of heavy metals like vanadium, molybdenum, zinc, nickel, mercury, lead, copper, chromium, cadmium and arsenic took place from soils to vegetables (spinach, tomato and cauliflower) grown in industrially polluted soils of Gazipur and Keraniganj in Dhaka [46]. Industrial wastes and effluents are being released aberrantly on soils, into canals, rivers, along the road sides or in the vicinity of the industrial areas without any treatment where polluted river water is being used for irrigation purpose in paddy and vegetable cultivation causing absorption of heavy metals through the food chain by human beings [47]. 


\subsection{Food adulterants}

Important food hazards include microbial hazards, pesticide residues, misuse of additives, chemical contaminants, including biological toxins and adulteration. Although microbiological contamination and chemical hazards have received most attention, it is recognized that food adulteration and food fraud should not be neglected considering their role in public health [48]. Food adulteration includes various forms of practices, such as mixing, substituting, concealing the quality of food by mis-labelling, putting up decomposed or expired food, and adding toxic substances [49]. About the proportion of adulterated food items in the market varied between $70 \%$ to $90 \%$. Nearly $80 \%$ food items in the market were found contaminated in a random survey by public health laboratory of Dhaka City Corporation in 2004 [50, 51]. According to the International Centre for Diarrheal Disease and Research, Bangladesh (ICDDR, B), there is approximately 150 food items in the country. A study by the Institute of Public Health (IPH) revealed that more than $50 \%$ of the food samples they tested were adulterated. Textile dyes, which are highly injurious to health, are being randomly used to color many types of food. Fish is considered to be an essential protein for people of all ages. Many fish sellers spray fish with formalin in an assorted manner, it makes the fish or fruits stiff and keeps them looking fresh for longer. Undoubtedly human health is now under the possession of formalin, in our country about 400 tons formalin is being imported which are goes to human stomach, even though for laboratory or research purposes 100 tons of Formalin is quite enough, $80 \%$ of the imported formalin being added to food only for business purposes (Table 5).

\begin{tabular}{|c|c|c|}
\hline Contaminants & Food/Additives & Possible Outcome \\
\hline $\begin{array}{l}\text { Coloring agents chrome, tartzine and } \\
\text { erythrosine }\end{array}$ & Spices, sauces, juices, lentils and oils & $\begin{array}{l}\text { Cancer in kidney, liver, skin, prostate } \\
\text { and lungs }\end{array}$ \\
\hline Rye flour (ibid) & Barley, bread and wheat flour & Convulsion and miscarriage \\
\hline Hormone (ibid) & Cauliflower & Infertility of women \\
\hline Coal tar and industrial Dyes & $\begin{array}{l}\text { Sweets, Sauce, Pastry cream, } \\
\text { powders spices }\end{array}$ & Carcinogenic \\
\hline Burnt oil & Crispy snack & Food poisoning, reflux, heartburn \\
\hline Shad Fish (Imported) & Heavy Metal (Cadmium, Lead) & $\begin{array}{l}\text { Over safe consumption level shows } \\
\text { heavy metal toxicities. }\end{array}$ \\
\hline $\begin{array}{l}\text { Agenomato or } \\
\text { monosodium glutamate (ibid) }\end{array}$ & Chinese restaurant food items & $\begin{array}{llll}\text { Nervous } & \text { system } & \text { disorder } & \text { and } \\
\text { depression } & & & \\
\end{array}$ \\
\hline Flour & Chalk Powder & GI problems \\
\hline Soap & $\begin{array}{l}\text { Ghee (Clarified butter made from the } \\
\text { milk of a buffalo or cow, used in } \\
\text { South Asian cooking) }\end{array}$ & GI problems \\
\hline Calcium Carbide/Ethylene dioxide & Ripening of fruits & $\begin{array}{l}\text { Cancer in kidney, liver, skin prostate } \\
\text { and lung }\end{array}$ \\
\hline Urea (ibid) & For whiten rice and puffed rice & Damage of kidney and nervous \\
\hline
\end{tabular}




\begin{tabular}{|c|c|c|}
\hline & & system, Respiratory problem \\
\hline Brick Dust & Chili powder & Respiratory problem \\
\hline Sulfuric acid and palm oil & Condensed milk & Cardiac function problem \\
\hline $\begin{array}{l}\text { Saw dust, Used and exhausted tea } \\
\text { leaves }\end{array}$ & Loose Tea & Respiratory problem \\
\hline Sodium cyclamate & Sweetmeat & Cancer, Fetal abnormality \\
\hline Metanil Yellow Aniline dyes & Turmeric powder & Carcinogenic \\
\hline Melamine & Milk Products & Kidney malfunction \\
\hline Oleomargarine or lard & Butter & $\begin{array}{l}\text { Asthma and weakened kidney } \\
\text { function }\end{array}$ \\
\hline Yellow and Sudan Red colors (ibid) & Chili powder & $\begin{array}{l}\text { Tumors in liver and bladder and } \\
\text { finally for cancer }\end{array}$ \\
\hline DDT & Dried fish (Shutki) & $\begin{array}{l}\text { Cancer especially breast cancer, liver } \\
\text { cancer and pancreatic cancer, } \\
\text { reproductive damage (Weaken semen, } \\
\text { early menopause, exposure of } \\
\text { teratogen and birth defects) and some } \\
\text { neurological damage reported. }\end{array}$ \\
\hline Coliform Bacteria & Bottle and Jar water & GI problems \\
\hline Formalin & $\begin{array}{l}\text { Preservation of fish, meat, fruit and } \\
\text { milk }\end{array}$ & $\begin{array}{l}\text { Throat cancer, blood cancer, } \\
\text { childhood asthma and skin-diseases. }\end{array}$ \\
\hline $\begin{array}{l}\text { Poisonous coloring agents like } \\
\text { auramine, rhodamine b, malachite } \\
\text { green, yellow G, Allura red, and } \\
\text { Sudan red }\end{array}$ & $\begin{array}{l}\text { Applied on food } \\
\text { items for coloring, brightness and } \\
\text { freshness }\end{array}$ & $\begin{array}{l}\text { Damage liver and kidney and cause } \\
\text { stomach cancer, asthma and bladder } \\
\text { cancer }\end{array}$ \\
\hline
\end{tabular}

Table 5: Toxic elements in noxious addition of food/additives [47, 50, 51-62].

Milk in rural areas is usually devaluated with dirty water, which can cause hepatitis. People are now acquainted with the milk adulteration technique that uses a thickening agent, sorbitol, and detergent. ICDDR, B recent studies shows nearly $75 \%$ samples from primary-level producers were contaminated with coliform and more than $50 \%$ with fecal coliform bacteria. At the collection points, samples were found contaminated with a high number of coliform bacteria and fecal contamination of more than $90 \%$ while more than $40 \%$ of the samples had a high E coli count. [57]. Vegetable and fruit samples collected from around Savar, Dhamrai and Tongi show the presence of textile dyes, which, in the short-term, will cause diarrhea, food poisoning and gastrointestinal problems, but in the longterm toxic materials will accumulate in the body with serious health implications. In the absence of effluent treatment plants (ETP), the factory wastes are depleted out at will into the farmlands, and ultimately contaminate the 
farm produce (uhavepassed.com). In Bangladesh, people allowed things like pollution and food contamination to run riot. Till now, neither under the health ministry nor the ministry of science and technology or the ministry of industries, has conducted any examination of the pesticide- residue levels or toxic chemicals in the foodstuff being marketed. These merchants and traders are the enemy not only of the nation and their own children but of the entire mankind. The holy Prophet (PBUH) has disowned those who indulge in this immoral business. He said "The adulterator is not one of us" [63]. Apart from these severe noxious pathogens found in different food samples (Table 6), that are potential causes of stomach problems.

\begin{tabular}{|c|c|c|}
\hline Presence of organisms in food/water & Overall $n=56$ & \\
\hline Organisms present in Food & n $(\%)$ & $95 \% \mathrm{CI}$ \\
\hline Yeast and mould (>100 CFU/mg) & $48.0(85.7)$ & $0.74-0.93$ \\
\hline Coliforms (>100 CFU/mg) & $41.0(73.2)$ & $0.59-0.84$ \\
\hline B. cereus $(>100 \mathrm{CFU} / \mathrm{mg})$ & $27.0(48.2)$ & $0.35-0.62$ \\
\hline E. coli $(>100$ CFU/mg) & $17.0(30.4)$ & $0.19-0.44$ \\
\hline Staphylococcus (>100 CFU/mg) & $8.0(14.3)$ & $0.08-0.27$ \\
\hline V. cholera & $2.0(3.5)$ & $0.01-0.14$ \\
\hline Organisms present in Water & Overall $n=16$ n (\%) & $95 \% \mathrm{CI}$ \\
\hline Total coliforms & $16.0(100)$ & - \\
\hline Faecal coliforms & $16.0(100)$ & - \\
\hline Total aerobic bacterial count & $16.0(100)$ & - \\
\hline Yeast & $16.0(100)$ & - \\
\hline Mould & $16.0(100)$ & - \\
\hline Staphylococcus & $16.0(100)$ & - \\
\hline E. coli & $10.0(62.5)$ & $0.35-0.86$ \\
\hline Faecal streptococci & $9.0(56.3)$ & $0.29-0.79$ \\
\hline Pseudomonas & $7.0(43.8)$ & $0.21-0.71$ \\
\hline
\end{tabular}

Total coliforms and fecal coliforms count (CFU/g) [63].

Table 6: Detection of foodborne pathogens in food and household water samples collected at point of use from four slums of Dhaka city, Bangladesh, December 2015 to May 2016.

It is an unfortunate reality that adulteration, especially in food, has become ubiquitous in the society. No one can justify or defend it. Most food products available in the market are adulterated. The average family is eating dangerous colors, chemicals like formalin and carbide, sawdust, soapstone, harmful chemicals and other harmful substances mixed with consumable goods. High level of pesticides content is present in grains, pulses, in fruits and vegetables that we eat [65]. Fecal bacteria found in 97\% bottled water [66]. Brick dust in chili-powder, colored 
chalk powder in turmeric, injectable dyes in watermelon, peas, capsicum, brinjal, papaya seeds in black pepper etc. are frequently used [63]. Even more unfortunate is the fact that this nefarious practice increases exponentially during the month of Ramadan. The shopkeepers and the merchants-many of them with a pious facade-try to earn a large amount of profit by this unethical practice, and so they play with the life and health of the people $[67,68]$. They mix dangerous things in the daily eatables. Even the medicine and drugs are adulterated. Most people can't even think of having the commodities like ghee, oil, salt and milk, free from impurities.

\section{Recommendations}

Pollution and contaminant control are a never ending, on the other hand a continuous process. It will increase with time as the civilization go ahead. Pharmacists should be aware of the local occupations, companies, and factories and to be cognizant of the initial symptoms of disease. Again, pharmacists should become acquainted with the local community and to adapt the principles of health and medical care to the particular situations encountered. The pharmacist's continuing education requirements should include watching the local pattern of society and its diseases, and changing the emphasis toward evolving disease patterns and their control. Included in the current environmental issues are the workplace and the future of occupational safety and health regulations, hazards of local ambient environments, such as hazardous and other waste dumps, radioactive waste from weapons production, air emissions, and groundwater contamination of unknown magnitude; the Clean Air act and other and regulatory initiatives; waste reduction and minimization, and radioactive waste and weapons production; global pollution, chlorofluorocarbons and the land ozone layer, the greenhouse effect, and global climate change; and conserving the tropical forest and biological diversity. Government and regulatory authorities are to play strong role in controlling food contaminants and adulteration. An out of the box thinking is decentralization i.e. to move few many important originations away from Dhaka city. With this decentralization, population density will be declined, the ill movement of business Crips will also be diluted.

\section{Conclusion}

With constant change to the physical, biological, cultural, social, and economic environment, both pharmacists and citizens should cultivate an informed awareness of these changes, and health providers should adapt their methods of health education, disease prevention, and disease control to the changes in each community. With an unusually large number of people seeking relief from health hazards, providers may play a much more fundamental and personal role in controlling food-borne diseases. The necessary role in environmental health is related primarily to being alert to the conditions prevailing in the community and of working with others to adequately control any of the attendant hazards.

Compliance with The Ethical Issues: Ethics approval and consent to participate Animal and Human experiment: N/A

Human Data Submission Approval: N/A 


\section{Consent for Publication}

Consent to publish Individual Person's data: N/A

\section{Availability of Data and Materials}

Data sharing: Data will be provided on request.

\section{Competing Interests}

The author declares that he has no competing interests

\section{Funding}

Funding from individual/Organization: No fund is received from any individual/organization.

\section{Authors' Contributions}

The individual contributions of authors: N/A

\section{References}

1. United Nations. $68 \%$ of the world population projected to live in urban areas by 2050 , says UN. Department of Economic and Social Affairs New York (2018).

2. Benedito B. Enhancing water security in urban areas. Euractive (2018).

3. NewNation. Enhancing water security in urban areas (2018).

4. Daily Sun. SDG-6: Access to Safe Water in Bangladesh (2018).

5. Joal K, Wendell C, Ali M, et al. The Problem with the Megacities. Champan University Press (2014).

6. Shishir R. Is there enough water?. DhakaTribune (2018).

7. MAA Jahan, $\mathrm{N}$ Akhtar, NMS Khan, et al. Characterization of tannery wastewater and its treatment by aquatic macrophytes and algae. Bangladesh J Sci Ind Res 49 (2014): 233-242.

8. Timothy JI, Ara HD. Pharmacists and Public Health Chapter 7, Eds.: David B. Troy, Paul Beringer Lippincott, Williams, et al. Remington: The Science and Practice of Pharmacy (2006).

9. WHO Section I. Health Impacts of Ambient Air Pollution Frequently Asked Questions Ambient and Household Air Pollution and Health Update (2014).

10. Ahmad KM, Marziat R. Dust pollution in winter. NewNation (2018).

11. Kun Y, Jeffrey LJ, Doug A, et al. Global Distribution of Outbreaks of Water-Associated Infectious Diseases. PLoS Negl Trop Dis 6 (2012): 1483.

12. Wasim MA, Dwaipayan S, Ashim C. Impact of pesticides use in agriculture: Their benefits and hazards. Interdiscip Toxicol 2 (2009): 1-12.

13. Foodborne Illness and Outbreak Investigation Manual. Kansas Department of Health and Environment Division of Health Office of Surveillance and Epidemiology 1000 SW Jackson, Suite 210 Topeka, KS 666 (2008). 
14. Sadiqur R, Rashad A. Pollution all around A cross-section of people share their opinions with New Age Staff Correspondents. NEW AGE Bangladesh (2018).

15. Azmin A. 5 Reasons Dhaka Is The Best City In The World. The Daily Star (2015).

16. Pooja D. What is it like to live in Dhaka, Bangladesh?. Traveller Comment Quora (2017).

17. The Global Livability Index 2018. A free overview A report by The Economist Intelligence Unit (2018).

18. Environment Desk World Bank report 18, 000 died from pollution in Dhaka city in 2015: WB businessnews24 (2018).

19. Chen TM, Gokhale J, Shofer S, et al. Outdoor air pollution: nitrogen dioxide, sulfur dioxide, and carbon monoxide health effects. Am J Med Sci 333 (2007): 249-256.

20. Daily Prothom Alo. City air pollution marks fall over one decade: Expert. UNB. Dhaka (2014).

21. Mohammad ZA, Eva A, Manjurul H, et al. Air Pollutants and Their Possible Health Effects at Different Locations in Dhaka City. Int J Environ Sci Nat Res 9 (2018).

22. Stanford News. Stanford researchers discuss the reality of air pollution in the Bay Area and beyond (2018).

23. Imtiaz S. Dhaka ranks second worst in Air Quality Index. DhakaTribune (2018).

24. Independent Online Desk. Dhaka awaits greater environmental hazards: Experts. The Independent (2018).

25. DhakaTribune. Study: Deadly air pollution shortens lives by nearly 2 years (2018).

26. Ferdous AB. Focusing on overuse and pollution of water. The Financial Express (2017).

27. Asif MZ. Dhaka and her rivers A beautiful relationship gone sour. The Daily Star (2017).

28. WHO. Chapter 8. Controlling infectious diseases in the environment. Guide to Ship Sanitation. ( $3^{\text {rd }}$ Edn.). Geneva: World Health Organization (2011).

29. UN Secretary General. Water-Related Diseases Responsible For 80 Per Cent of All Illnesses, Deaths In Developing World. Environment Meetings Coverage and Press Release Day Message Secretary-General Kofi Annan for World Environment Day (2003).

30. Malik A, Yasar A, Tabinda AB, et al. Water-Borne Diseases, Cost of Illness and Willingness to Pay for Diseases Interventions in Rural Communities of Developing Countries. Iran J Public Health 41 (2012): 3949.

31. UNDP Pollution. Abatement Strategies for Rivers and Wetlands in and Around Dhaka City Parliamentary Standing Committee on Ministry of Environment and Forests (2010).

32. Manoj S, Melissa A. The Dhaka Water Services Turnaround (C 2017 Asian Development Bank (2017).

33. Murshed S, Ali MH, Faruque MO, et al. Analysis of WASA Supplied Drinking Water Around Dhaka City from Laboratory Analysis Perspective. International Journal of Chemical and Physical Sciences IJCPS 2 (2013): 20-27.

34. Daily Asian Age. Rethinking urban ecology for sustainable development (2018).

35. Inam A, Refayet UM. Water: Garments' invisible price. The Daily Star (2017).

36. Mitali P, Anwara B. Organic Solid Waste Management and the Urban Poor in Dhaka City. Int J Waste Resour 8 (2017): 320. 
37. Abu HM. Medical, chemical and radioactive waste. Whose responsibility is it anyway?. DhakaTribune (2018).

38. Mohiuddin AK. Medical Waste: A Nobody's Responsibility After Disposal. Int J Environ Sci Nat Res 15 (2018): 555908.

39. Mohammad GR, Islam F, Mohammad MKH. Environmental pollution generated from process industries in Bangladesh. Int J Environment and Pollution 28 (2006).

40. Shishir R. Upholding corporate environmental responsibility and accountability. The Independent (2017).

41. Manzurul MH, Azam SA, Anisur KR, et al. Pattern of medical waste management: existing scenario in Dhaka City, Bangladesh. BMC Public Health 8 (2008): 36.

42. Simonsen L, Kane A, Lloyd J, et al. InFocus Unsafe injections in the developing world and transmission of bloodborne pathogens: A review. Bulletin of the World Health Organization 77 (1999): 789-800.

43. MA Hashem, MS Nur-A-Tomal, MJ Abedin. Heavy metal assessment of polluted soil around Hatirjheel Lake of Dhaka city, Bangladesh. Bangladesh J Sci Ind Res 52 (2017): 61-66.

44. Mahmudul IM. Toxicity of Heavy Metals In Soils And Crops And Its Phyto-Remediation Dissertation For Phd Department Of Soil, Water And Environment university Of Dhaka. Dhaka-1000 (2015).

45. Ashiqur R, Jahan SA, Khairul B, et al. A Comparative Study of Heavy Metal Concentration in Different Layers of Tannery Vicinity Soil and Near Agricultural Soil American. Journal of Analytical Chemistry 7 (2016): 880-888.

46. Rafiqul MI, Jahiruddin M, Alim MA, et al. Consumption of Unsafe Foods: Evidence from Heavy Metal, Mineral and Trace Element Contamination. June 2013 Study supported by NFPCSP National Food Policy Capacity Strengthening Program USAID FAO (2013).

47. Zubair KL, Mohiuddin AK, Bake MA. Food Contaminants: Bangladesh Perspective (2013).

48. FAO/WHO. Assuring food safety and quality: guidelines for strengthening national food control systems. Rome: Food and Agriculture Organization (2003): 28.

49. Park K. Park's textbook of preventive and social medicine. (1 $8^{\text {th }}$ Edn.) Jabalpur: Banarsidas Bhanot (2005): 481.

50. Staff Correspondent. Food adulteration rings alarm bell STAR-RDRS roundtable told most food items adulterated, pose lethal risks to public health. The Daily Star (2011).

51. Mirza FIC. Evaluating Position of Bangladesh to Combat 'Adulterated Food' Crisis in Light of Human Rights. IOSR Journal Of Humanities And Social Science (IOSR-JHSS) 19 (2014): 45-54

52. Mohammad S. Heavy Metal' in Imported Fish: Samples sent for retest. The Daily Star (2018).

53. Rahman MA, Sultan Z, Rashid MA, et al. Food Adulteration: A Serious Public Health Concern in Bangladesh. Bangladesh Pharmaceutical Journal 18 (2015): 1-7.

54. Nishat TS. Food adulteration: A serious health risk for Bangladesh (2017).

55. Abu NMAA. Food Safety and Public Health Issues of Bangladesh. European Food and Feed Law Review (2013): 31-40. 
56. Nehreen Majed, Md Isreq H Real, Marufa Akter, et al. Food Adulteration and Bio-Magnification of Environmental Contaminants: A Comprehensive Risk Framework for Bangladesh. Front Environ Sci (2016).

57. NewsDesk. Over 75\% pasteurised milk unsafe for direct consumption in Bangladesh: ICDDR, B study. bdnews24.com (2018).

58. Shafkat R. Letters To The Editor Urea in puffed rice. The Daily Star (2013).

59. Sharifa N, Tahmeed A. Food Adulteration and Consumer Awareness in Dhaka City, 1995-2011. J Health Popul Nutr 32 (2014): 452-464.

60. Rajib KR. Cover Unsafe Food Unhealthy Life. Daily Sun (2015).

61. Editorial. Look for the flies-the future ahead!. Bangladesh J Medicine 25 (2014): 40-41.

62. Mahboob MS. Food Adulteration: The Bangladesh Paradox. Law Journal Bangladesh 2 (2015).

63. Editorial. Food Adulteration. The Independent (2017).

64. Ishita M, Nurun NN, Mustafa M, et al. Children living in the slums of Bangladesh face risks from unsafe food and water and stunted growth is common. Acta Paediatrica 107 (2018): 1230-1239.

65. Kamruzzaman M. Formalin Crime in Bangladesh: A Case Study. European Journal of Clinical and Biomedical Sciences 2 (2016): 39-44.

66. Staff Correspondent. Govt study finds faecal bacteria in 97 percent 'filtered' water jars in Dhaka (2017).

67. Star Business Report. 36 Ramadan food items fail BSTI tests. The Daily Star (2018).

68. Zameer M. What you eat during Ramadan. Dhaka Tribune (2017).

69. Megacity Challenges. A stakeholder perspective. A research project conducted by GlobeScan and MRC McLean Hazel Sponsored by SiemensAG. Siemens AG Corporate Communications (CC) Wittelsbacherplatz 2, 80333 Munich (2004).

70. Uhavepassed.com. Adulteration of Food in Bangladesh (2014-2018).

Citation: Mohiuddin AK. Chemical Contaminants and Pollutants in the Measurable Life of Dhaka City. Journal of Environmental Science and Public Health 3 (2018): 57-73.

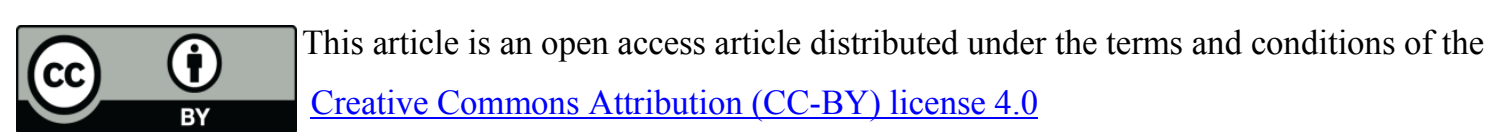

